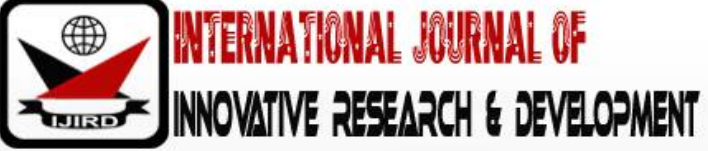

ISSN 2278 - 0211 (Online)

\section{Theism and the Problem of Evil: A Critical Study}

Dr. Kushi Wakili Polmi
Student, Department of Theological Studies,
Agape Christian Theological Seminary, Abuja, Nigeria
Batum llisha
Student, Department of Theological Studies,
Agape Christian Theological Seminary, Abuja, Nigeria
Ubong Aniema James
Student, Department of Theological Studies,
Agape Christian Theological Seminary, Abuja, Nigeria

\begin{abstract}
:
I argue that the problem of evil can be a moral objection to theistic belief. The thesis has three broad sections, each establishing an element in this argument. Section one establishes the logically binding nature of the problem of evil: The problem of evil must be solved, if you are to believe in God. And yet, I borrow from J. L. Mackie's criticisms of the moral argument for the existence of God, and argue that the fundamentally evaluative nature of the premises within the problem of evil entails that it cannot be used to argue for the nonexistence of God. Section two establishes the moral objection ability of many responses to the problem of evil (theodicies). I discuss the work of the moral 'anti-theodicists', and support some of the key premises within their arguments via appeal to the moral philosophy of Raimond Gaita. I combine the claims of section one and section two, and conclude that theism inherits the moral objectionability of theodicy. In section three, I establish the plausibility of a morally motivated non-cognitive atheism, offering an example (Dostoevsky's Ivan Karamazov), before finally distilling the central claims of this thesis into the form of a slogan: God lacks humanity.
\end{abstract}

Keyword: Theism, problem of evil, argument, god, theodicy

\section{Introduction}

The problem of evil remains a central problem for any religious believer, and continues to feature prominently in the analytic philosophy of religion. My thesis will look once again at the problem of evil, and begins with the fairly obvious observation (often ignored) that certain ethical and metaethical assumptions are essential to the meaningfulness of the problem of evil. We cannot make sense of what a problem of 'evil' is unless we have some working understanding of what it is for something to be 'evil'; we cannot make sense of the problem of evil as a problem for theism unless we have some working understanding of what we mean when we say that God is good. Any argument from evil must take a stance on these issues if it is to be meaningful, and if it hopes to have any argumentative impact then its stance on these issues must relate to the theism that it seeks to deny. The argument from evil, therefore, relies fundamentally upon certain ethical assumptions. Furthermore, any defence against the argument from evil, in the form of a theodicy, must also be founded upon certain ethical assumptions; the theodicy too must take a stance upon these issues of what we mean by 'evil' and 'God is good'.

These may seem like obvious points, but they are sadly neglected in the philosophical discussion of the problem of evil. The purpose of this thesis is to bring these points to consciousness, and to look at some of the consequences that they entail, both for religious belief and for the arguments that seek to act as defeaters for religious belief

\section{The Problem of Evil}

The problem of evil does not set out to say anything about the world. Rather than arguing for any particular conclusion, its aims are to prompt the theist to establish consistency within their beliefs. Reprising the simple form, it looks something like this:

- P1. There exists a maximally-good, maximally-powerful creator of the universe.

- P2. A maximally-good, maximally-powerful creator of the universe would not create or permit any evil in its creation.

- P3. Some evil exists.

This form is clearly reminiscent of the argument from evil: P, P $\neg$ Q Q Q It is an inconsistent set of propositions; it is not possible without contradiction to assert all three propositions as true simultaneously; the truth of any two entails the falsity of the remaining third. The 'problem' is that all three appear to be at least prima facie true for a theist. Therefore, 
the theist must face the challenge of resolving an apparent inconsistency within their beliefs by denying at least one of the premises - this is what it means to 'solve' the problem of evil.

The theist is entirely free in how they do this. They could adopt either of the theodical strategies mentioned in the previous section, so finding a way to deny P2 or P3. Alternatively, they could maintain the truth of P2 and P3, and be forced to reject P1, so accepting atheism, or significantly modifying traditional theism. The point of the logical problem of evil is that the theist must do either of these if they are to avoid endorsing the truth of an inconsistent set of propositions. This 'must' is forced with the force of a logical must, mandated by the law of non-contradiction.

That the rejection of $\mathrm{P} 1$ is intuitively considered the most natural solution for the problem of evil is the reason the argument from evil gets off the ground, so it is not surprising that the lines between the two variations get blurred. And, certainly, one might be thought of as relying upon the other; perhaps the argument from evil ought to be thought of as an extension of the problem of evil. But this extension would only be warranted to the extent that we were certain of the truth of premises P2 and P3. If a theodicy's gives us reason to doubt the truth of either of those, then the motivation for moving towards the argument from evil is weakened.

The key difference between the two variations (i.e., argument and problem) is the stated aims and intended conclusions. The argument from evil seeks to establish the nonexistence of God; the problem of evil seeks only to establish consistency - or rather, resolve the apparent inconsistency - within the theist's beliefs. Both variations are logical', if by logical' we mean relying upon a notion of deductive validity, but they do not necessarily share the same level of commitment, nor therefore the same level of success.

For success is to be determined by the extent to which each variation achieves its stated aim, and the stated aims are very different. That Plantinga successfully weakens the argument from evil, to such a degree that it might be considered to have failed, does not entail that we can no longer present the logical version of the problem of evil. Since the failure of the argument from evil in no way entails the failure of the problem of evil, the logical problem still applies.

Plantinga's original response to Mackie did defeat the logical status of the problem of evil as formulated by Mackie, but only because Plantinga claimed the special requirement that any additional premises must be necessarily true. This special requirement was only generated from the very specific task of looking for an implicit contradiction within Mackie's original three propositions. I do not see why we should accept this special requirement in all cases and apply it to components in every formulation of the problem of evil, even if it does apply to Mackie's formulation. We can easily formulate versions of the problem of evil that are deductively valid, even if their corresponding argumentative formulations remain rhetorically weak. Plantinga has given an excellent reason to deny that there are deductively sound arguments from evil, but no good reason to deny that there are deductively valid formulations of the problem of evil.

\section{God Does Not Exist}

Perhaps the most plausible and therefore easiest solution, but not one that many theists are going to be willing to accept. It remains a 'solution', in that it would resolve the inconsistency present in the set of premises by denying one of the premises; namely, the one that says that God exists.

\section{God Is Not Maximally-Good}

Problematic for most theists. Remember that this premise does not specify (yet) what God's goodness amounts to. All it says is that whatever 'goodness' is, God has it (or perhaps is it) maximally. To deny this is to say something that runs contrary to swaths of theological tradition.

\section{God Is Not Maximally-Powerful}

Perhaps slightly less problematic than denying God's maximal-goodness, and certainly an option that many theologians have been willing to consent to. Perhaps 'process theology' is the best example of this, but John Bishop has also defended a view along these lines.9 In any case, this would impose more severe limits on God's power than the already limiting stipulation of 'no non-logical limits', and we might want good reason to accept the truth of this new limitation, other than as an ad hoc response to the challenge of the problem of evil.

\section{God Is Not a Moral Agent}

To my mind this is by far the most plausible solution for a theist, one that is taken up by many theologians, theists, and atheists. D. Z. Phillips argues effectively for the conclusion that we should not think of God as sharing our moral community. Similarly, Brian Davies says: Theologians have taught that God is good without holding that his goodness is that of a morally good agent.' This is a solution that has sound theological mandate: The Bible is quite happy to say that God's ways are not our own.12 It might seem dubious, therefore, that I have labelled this premise as being 'essential to theism'. The justification for this claim comes from the observation that to deny that God is a moral agent is to equivocate absolutely between what we are willing to say of God in this context (i.e., the context of the problem of evil) and what we are willing to say of God in other contexts. That is, if even once God is described as 'acting', and operates with 'reasons' that are (broadly understood) 'moral', then God is a moral agent. Theological tradition is replete with examples of God's being understood as acting in this way. If God 'creates' and sees creation as 'good', then we seem to have an example of this kind. Even limiting ourselves to the context of the problem of evil, we can find many similar examples: God 'forgives sins', God 'compensates for suffering', perhaps God even 'punishes wrongdoing'. Given the range of examples readily available to us to justify the claim that God is a moral agent, it seems that we must therefore either commit to God's being a moral agent, or else dismiss all of these instances in which God is purported to act morally. 


\section{Theism Tends to Entail Non-Consequentialism}

This strikes me as profoundly intuitive, and therefore there seem to be many things that could be offered in its defence. We could talk about the scriptural support seeming to condemn a consequentialist moral attitude; we could talk about the many instances of Church authority speaking out against a consequentialist ethical outlook; we could talk about the philosophical reasons that seem to compel someone who believes in God away from adopting a consequentialist moral attitude; and I will talk about all of these in turn. But I recognise that none of these would be conclusive to the establishment of premise 1. There are always going to be exceptions to the rule in this case; I cannot claim that all theists are not consequentialists, and neither can I hope to claim (conclusively) that they should not be. All I can point out is that, generally speaking, theists do not tend to be consequentialists in their normative assumptions, and I think they have good reason not to be. I can offer the aforementioned reasons in support of this general claim, but they will only be true insofar as the empirical claims are accurate, the scriptural claims accepted theologically, and the philosophical claims agreed upon. This confines the scope of my conclusion to only those theists for whom the above are true, but I am quite happy with this. All valid arguments can be re-phrased as conditionals, after all, and all conditionals are prefaced with an 'if'. So if you think the first two premises are true, then you will be faced with my dilemma.

\section{Soul-Making Theodicy Is Consequential List}

John Hick's 'Soul-Making Theodicy' responds to the problem of evil by asserting that God has a certain end in mind for which certain means - means which unfortunately involve some evil - are required. The end sought...is the full realization of human potential in a spiritual and moral perfection within the divine kingdom', and this end requires that we gradually mature in a hostile environment, for this is the only way in which we can truly achieve it. God creates and allows evil to exist because it is better, all things considered, this way than any other. That it is better' is determined by the outcome, or the consequences of doing things this way. It is right that God arrange the universe this way because of the consequences of arranging the universe in this way. This is an important point, and one that should not be ignored or underestimated.

According to SMT, and many other theodicies that appeal to a kind of 'greater good' reasoning, God is morally justified in permitting certain evils, or creating a universe in which certain evils will occur, by the consequences of His so permitting. It is right that God does such and such because it is best overall that He does so. According to SMT, the 'best' is the 'end sought'. As such, the good is here being defined exclusively in terms of consequences. The important point to recognise is not only that SMT expresses goods in terms of consequences, but that it explicitly states that God's reasons for permitting evil are because of these goods (defined in terms of consequences). According to this story, the goods (defined in terms of consequences) are not a by-product of some otherwise good scheme; they are the feature that makes the scheme good. As such, consequentialism is revealed to be even more embedded in SMT than even a cursory glance at its reference to 'good outcomes' would suggest.

\section{Moral Anti-Theodicy}

Albert Camus

One cannot ask suffering to justify its reasons. One would expose oneself to empathizing with nearly nothing.

This apology, in which the vindication is worse than the complaint, needs no refutation; surely it can be freely given over to the detestation of every human being who has the least feeling for morality.

Immanuel Kant

In the previous chapter, we noted an apparent inconsistency in the normative assumptions deployed by theists in various ethical contexts. Specifically, theists seem generally averse to consequentialist moral reasoning in most ethical discussions, yet appear generally in favour of deploying consequentialist justifications when it comes to discussing the problem of evil. This built upon the work of the preceding chapters of this thesis, which sought to highlight the important role that evaluative claims, and underlying normative assumptions, play in both the proposition of the problem of evil and its attempted refutation. I argue that disagreements regarding the problem of evil are, in the main, distinctively moral disagreements, and as such ought to be dealt with using the best tools that we have at our disposal - namely, those of moral philosophy. Once we are sufficiently aware of the fundamental role that evaluative claims play within the problem of evil, this is the only sensible way that the discussion can continue. I will now turn to an example of the kind of discussion that results from an awareness of the fundamental role that evaluative claims play within the problem of evil: the discussion of moral anti-theodicy.

Moral anti-theodicy claims that there is something morally objectionable about the way in which theodicy goes about its work. A barrage of critical arguments have been brought to bear on the moral status of theodicy, from the likes of Nick Trakakis, D.Z.

Phillips, and Kenneth Surin. Each concludes that certain classical theodical solutions ought to be dismissed on moral grounds. I will dwell on these arguments at some length, but first I think it would be helpful, to provide some context, to say a little more about how theodicies work, and the particular steps that they take that might cause a moral anti-theodicist to take offence.

\section{How Theodicies Work, According To My Analysis}

I have argued that the problem of evil is made up of evaluative and non-evaluative content. Theodicies defeat the problem of evil; they find a way to deny the conclusion of the argument from evil, or find a way to resolve the problem of evil, by denying the truth of one of the premises within the problem. But how do these theodicies work, at the meta level? Recall my meta-formulation of the problem of evil: 
- There exists a maximally-good, maximally-powerful creator of the universe.

- A maximally-good, maximally-powerful creator of the universe would not create or permit any pointless or unconscionable evil in its creation.

- $\quad$ Some pointless or unconscionable evil exists.

If my analysis is correct, then theodicies deny some part of premise 1 (relating to the existence of God), deny some part of premise 3 (relating to the existence of evil), or else deny that the existence of God and the existence of evil are incompatible (i.e. deny premise 2). I have claimed that these premises are made up of evaluative and non-evaluative components. Which do theodicies deny, the evaluative or the non-evaluative components?

We can ignore a denial of premise 1 for now, for that is mostly considered conducive to atheism. We must focus on premises 2 and 3. Consider premise 3: In its simplest form 'Evil exists', or as I have it in my meta-formulation 'Some pointless or unconscionable evil exists', or in its more complex form 'An event $\mathrm{x}$ happens, and it is bad that x happens ( $\mathrm{x}$ ought to have been prevented by any being who had the power to do so).' Clearly, theodicists cannot deny the nonevaluative content of this premise; no one can deny that earthquakes happen, or that suffering occurs. What theodicists deny, if they wish to deny the truth of this premise, is the evaluative content. That is, they accept that earthquakes happen, but they deny that such an earthquake is 'bad', all things considered, or otherwise ought to have been prevented by a being who had the power to do so. Theodicies deny premise 3 by bringing in a further evaluative claim, one that undermines and trumps the initial evaluative claim contained within premise 3. A theodicy might claim that it is justified that such an earthquake should occur, for it provides us with opportunities for moral growth, etc. This is an evaluative claim; it is good that we attain moral growth, and the permission of earthquakes (by a being who had the power to do otherwise) is morally justified in light of this.

Similarly, consider premise 2: 'A maximally-good, maximally-powerful creator of the universe would not create or permit any pointless or unconscionable evil in its creation.' I have claimed that this entailment is an expression of the perceived contradiction between the evaluative contents of premises 3 and 1. So, in Mackie's sense, that 'a being who is wholly good eliminates evil as far as he can'; or in my sense, that being maximally-good (as a moral agent) entails that you do all that you ought to, where what is 'evil' in this context (as an event) is understood to mean 'ought not to be permitted by any being who has the power to do so'. I have claimed, in my meta-formulation, that this entailment is intended as an expression of the meaning of the terms within premises 1 and 3. As such, to deny the truth of this entailment is to deny the meaning of the terms within premises 1 and 3. And, again, what is likely to be being denied here, the meaning of the terms relating to the non-evaluative claims - what it means for an earthquake to occur, for God to have power, etc. - or the meaning of the terms relating to the evaluative content - what being 'maximally-good' entails, what an event being 'evil' entails? It seems clear that theodicy works, in either case, by denying or challenging the truth or meaning of some of the evaluative components within the problem of evil. This can only be done by bringing in further evaluative claims that either undermine or else trump the initial evaluative claim contained within the problem of evil. Specifically, and speaking once again at the meta level, the claim of theodicy will almost always take the form of providing God with a morally sufficient reason for permitting the evils of the world.

Because this is how theodicy works, it remains likely that theodicy will always succeed in its aims of resolving the inconsistency within the meta-formulation of the problem of evil. I stress the 'always', because I really do mean that theodicy will always be capable of defeating the problem of evil. Given that all theodicy requires is the proposition of an additional moral truth (or evaluative claim), and given that it is incredibly difficult to establish the absolute truth or falsity of moral claims one way or the other - the history of normative ethics is testament to that fact - these additional moral claims are going to be fairly impervious to conclusive counter-attack. (This echoes a point I made earlier, in chapter three, that the underlying normative agreement necessary to come to some mutually acceptable conclusion is likely to be difficult to achieve.)

Because of this relative immunity to counter-attack, the theodicist has tremendous flexibility in how they go about their work, and great freedom in the variety of additional moral claims that they can invoke to establish their conclusion. In chapter three, section 3.3.3, we saw something of the range and variety of evaluative claims that have been offered as responses to the problem of evil; from John Hick's consequentialism to Simone Weil's 'God did not reserve the cross for Christ alone'. Some of these evaluative claims are less extreme than others, but all of them exploit a relative freedom in formulating their theodical narratives. It is not terribly important for these theodicists that some other people are not going to agree with their evaluative claims, since 'everyone knows' that such normative agreement is a rare thing anyway.

\section{Moral Anti-Theodicy}

My analysis of the problem of evil shows that the premises within the problem of (and argument from) evil contain some fundamentally evaluative claims. I have further claimed that theodicy works by denying some of these evaluative claims, and that this can only be done by invoking other evaluative claims. These further evaluative claims seek to undermine the overall, all things considered, 'badness' of any evil event that is posited in premise 3 of the problem of evil, or else seek to weaken the perceived incompatibility between the maximal-goodness of God, as expressed in premise 1, and the 'evil' of the event expressed in premise 3. As such, the evaluative claims of theodicy will do one of two things: Deny that the event in question is 'evil', all things considered, or deny that it is incompatible with 'maximal-goodness' or moral perfection. The response of the moral anti-theodicist is to reject either of these claims on purely moral grounds. That is, the moral anti-theodicist rejects the evaluative claims of theodicy with some evaluative claims of their own, or by re-asserting the strength of the original evaluative claims within the problem of evil.

I will focus on the work of D. Z. Phillips, Kenneth Surin, and Nick Trakakis. Each of these has offered their own distinct moral critiques of theodicy, but I do not think that it is unfair to group them all together as expressing the same 
basic point. They all, according to my analysis, reject those evaluative claims within theodicy that facilitate theodicy's defeat of the problem of evil, and they reject these evaluative claims on evaluative grounds.

The evaluative grounds on which theodicy's evaluative claims are rejected can be separated into six broad categories, which I will deal with in distinct sections. As will become clear, each of these bases for the rejection of theodicy on evaluative grounds bleed into one another, such that it is slightly artificial to separate them as I do. Nevertheless, for clarity I will treat them as distinct criticisms.

\section{Moral Insensitivity: Theodicy Fails To Take Suffering Seriously}

This is perhaps the most common and frequently recurring criticism of theodicy on evaluative grounds, that it does not take the suffering posited in premise 3 within the problem of evil sufficiently seriously. This point has been made by Phillips, Surin, Trakakis, and most others who have written on this subject, and is fairly labelled the central objection of moral anti-theodicy. It gives rise to an accusation of moral insensitivity, since to engage in the practice of constructing theodicies is to speak of the horrendous sufferings of the world as something that can be 'absorbed', or outweighed by some greater good, and to do this is to downplay the extremity of the horror involved. It is precisely the recognition of certain instances of suffering as being horrendous that confirms their irredeemable status. As such, to speak of the horrors of the holocaust in the same breath as one speaks of patently redeemable sufferings (such as going to the dentist), and to allow for some comparison in degree to be drawn between them, is to fail to recognise the qualitative, and not merely quantitative, severity of the horrors in question.

\section{Theodicy Exhibits an 'Irremissible Moral Blindness'}

Again following on from the previous criticisms, a combination of moral insensitivity and the adopting of too detached a perspective leads to an accusation of an 'irremissible moral blindness'. 'A theodicies who, intentionally or inadvertently, formulates doctrines which occlude the radical and ruthless particularity of human evil is, by implication, mediating a social and political practice which averts its gaze from the cruelties that exist in the world.' This accusation rests not only on what has been mentioned - the detached perspective causing one to be blind to the down-to-earth subjective realities of morality - but extends to a very specific anti-theodical objection, one that is worth discussing at some length, since it turns out to be rather controversial. The objection is that theodicy is blind specifically to the moral reality of unconscionable evils. That is, evils that are beyond justification by greater goods.

This point is powerfully expressed by Kenneth Surin. In response to the notion that we should remain openminded about the possibility that horrendous evils, such as the holocaust, could be justified by appeal to greater goods, Surin says this:

To be 'open-minded' about certain realities, and 'more tellingly' to insist on retaining such a contemplative disposition, is to show oneself to be incapable of making certain exigent moral discriminations. In the worst of cases, this incapacity to acknowledge that a particular reality is mind-stopping betokens an irremissible moral blindness, in less serious occurrences it testifies to a real lack of moral imagination, to an unshakeable moral coarseness. But in all cases the failure to lend a voice to the cries of the innocent (and there can be few more glaring instances of this failure than the willingness to construct a divine teleology out of innocent suffering) is to have lost the capacity to tell the truth: The need to lend a voice to suffering is a condition of all truth. For suffering is objectivity that weighs upon the subject; its most subjective experience, its expression, is objectively conveyed.' He continues:

In cases where human beings are in extremis, to be 'open-minded', and thus to deafen one's ears to their cries, is to repudiate their flesh-and-bloodness, their being human. And in this hedging of one's acknowledgement of the humanity of the other, one has lost one's own humanity. [...] There are moral reasons, and we can abide by them, spurn them, contemplate them, be convinced by them, and so forth. [...] In the domain where human beings have to think and act, there are irreducible realities - realities 'extra-territorial to reason' (to borrow a phrase of George Steiner's) - which halt the tongue, afflict the mind with blankness. To be resolutely 'open-minded' when confronted with these morally surd realities is to have lost any possible accordance with the truth (Adorno). It is to have lost one's own humanity (Cavell).24

Surin follows this paragraph with a particularly harrowing account of an incident in a concentration camp, and leaves it there, without further explanation or discussion. The account stands as an example of just the sort of 'morally surd realities' that theodicists, in seeking to fit such an event into a network of divine purposes, are blind to. No further explanation can be, or need be, offered to establish the truth of this irreducible moral reality.

\section{The Key Anti-Theodical Premise}

We can construct a simple little argument to make this key anti-theatrical point clear:

- There are unconscionable evils, which exist as 'morally surd realities'.

- If theodicy is true, then there are no unconscionable evils.

- Therefore, theodicy is not true.

- 3 follows from 1 and 2, and 2 is undoubtedly true. 1, however, turns out to be a very controversial claim.

Robert Mark Simpson objects to this premise on the basis that it is begging the question against the conclusion of theodicy. Theodicy seeks to argue that all evils are justified, the anti-theodical premise asserts that there are some evils that cannot be justified. As such, the key premise of anti-theodicy assumes that the conclusion of theodicy is false; or in other words, it begs the question against theodicy.

Although appearing to be a legitimate criticism to make, it rather misses the point of the anti-theodical premise. Namely, that the truth of this premise exists as a 'morally surd reality'. So yes, the anti-theodical premise does assume the negation of the conclusion of theodicy, but it does so because that assumption is unavoidable, fundamental, necessary. The 
anti-theodicist claims that this premise is basically true, and further claims that the basic truth of this premise is not something that is reducible to further argument. It exists as a brute reality, one which can only be revealed by example, and that we can either recognise or be blind to.

This, it is clear, is a rather bold meta-ethical claim, but it is not one that is vulnerable to accusations of questionbegging. Indeed, to accuse the anti-theodicists of question-begging on account of this seems only to invite a tu quoque response! D. Z. Phillips is all too ready to reply with his own accusation of question-begging. In those who construct theodicies, he says, 'there is an unreadiness to consider examples where the moral perspective involved is one which says that doing, or allowing, certain evils for the sake of a greater good is ruled out'. Or, in other words, the theodicists beg the question against the anti-theodicists in assuming the non-existence of unconscionable evils.

It is this sort of stalemate, each side seeming vulnerable to accusations of question begging, that leads certain philosophers to accept the stalemate, and become tempted to abandon the discussion. Speaking of the instrumentalism involved in theodicy, Stephen T.

Davis writes: 'Instrumentalism in this context is understood by Phillips as the attempt to justify human suffering as a means to something greater. And it is clear that Phillips finds this idea morally objectionable and untrue to the logic of moral responsibility. But I am afraid I don't, and I'm not sure what else can be said here.' I mentioned earlier, in chapter three, that this sort of pessimism regarding the prospects of moral philosophy was disappointing to see in such able philosophers. All we have here is an apparent aporia, but this is no reason to halt the discussion.

\section{Theodicy Does Not Understand How Morality Works}

The fourth anti-theodical objection could be seen as a combination of all of the above, in that it claims that theodicy does not understand how morality works. Theodicy seems to assume an unrestricted utilitarianism, and in doing so does not recognise the qualitative extremity of certain horrendous evils, the essential role that the subjective perspective plays in evaluative claims, and the moral reality of unconscionable evils. Combined, this gives the impression that theodicy just does not get how morality works; it is working with the wrong moral theory. As such, it cannot hope to yield accurate conclusions.

D. Z. Phillips illustrates this point with an argument that shows the self-defeating nature of certain features of a Soul-Making Theodicy (SMT). An element of SMT holds that one of the reasons God permits evils is that evils allow us the opportunity to develop character. As John Hick says, there is a divine end that we must strive to reach: The end sought...is the full realization of human potential in a spiritual and moral perfection within the divine kingdom.' This end requires that we gradually mature and develop our moral characters in a hostile environment, for this is the only way in which we can truly achieve it. But, Phillips points out, for God to permit evils for the instrumental purpose that we develop moral character is to defeat that very purpose!

To make the development of one's character an aim is to ensure that the development will not take place. This is because the endeavour so conceived is self-defeating: it lacks character.

[...] It seems to be both a logical and moral truth that to seek one's character development is to lose it.

We need to be clear about precisely what kind of 'character' Phillips is talking about here, since the logical truth' that 'to seek one's character development is to lose it' is not so obvious as Phillips assumes. There do seem to me to be some cases in which to seek one's character development is an admirable, characterful, pursuit. People often subject themselves to a certain degree of suffering in order to 'develop character'; the examples of religious ascetics, sportsmen and women, and martial artists spring to mind. One cannot deny that subjecting oneself to the discipline of, say, cycling as fast as one can up a mountain is a characterful act. And if the goal is nothing more than to develop one's character, to be hardier in the face of suffering, then the act of pursuing this character trait hardly seems to diminish the achievement. Similarly, parents might subject their children, and teachers might subject their pupils, to some suffering as a 'character building' exercise. Clearly, we should not assume from this, as theodicists are inclined to do, the principle that any suffering can be seen in this way. As Phillips says, there are screams and there are screams, and there is a qualitative difference between being pushed out of your comfort zone in order to develop character and being afflicted by horrendous suffering. Nevertheless, if cases like this are plausible, then it would seem to challenge the 'logical truth' that 'to seek one's character development is to lose it'.

But it is not this kind of 'character' that Phillips, or Hick, are talking about. They are referring specifically to moral character, and as such the idea is that to do something moral for purely self-regarding reasons of developing one's character is to detract from the moral worth of the act. Moral character applies to, as Phillips says, 'other things', rather than oneself. If someone dives into a burning building to save a puppy, this is undoubtedly an admirable act, showing great moral (and other) character; but if we learn that they did this solely for self-regarding reasons - to impress their friends, for monetary reward, etc. - then many would be inclined to see these self-regarding reasons as detracting from the moral worth of the action. (Consider further the even more clearly self-regarding situation in which the individual had both left the puppy inside and set the building on fire in order that they have the opportunity to 'develop their character'. It would be absurd to consider this a characterful pursuit.) And yet, if theodicy is correct, then these self-regarding reasons occupy a pivotal role in the permission of evils. To think this way 'involves the objectionable instrumentalism in which the sufferings of others are treated as an opportunity for me to be shown at my best. Ironically, if I think of their sufferings in this way, I am shown at my worst'.

\section{Theodicy Treats People as Mere Means}

The fifth anti-theodical objection could be seen as an example of the fourth. In failing to understand how morality works, and assuming a sort of unrestricted utilitarianism, theodicy falls into the trap of treating people as mere means, 
rather than as ends in themselves. This broadly Kantian doctrine is, it is claimed, a basic moral truth, and as such theodicy suffers if it ignores it. That theodicy misunderstands this basic moral truth is rendered particularly obvious in the following passage from Richard Swinburne:

It is because being of use is a good for him who is of use and increases his well-being, that when someone's suffering is the means by which they are of use that the net negative weight of their suffering-and-being-of-use is not nearly as great as it would otherwise be; and so our Creator, if he has given us many other good things has the right to use us to a limited extent for the sake of some good to others. Kant was surely correct to emphasize that one must treat individuals as moral ends in themselves and not use them for the good of others. But the latter phrase must be interrupted [sic, probably 'interpreted'] as 'on balance'. It is permissible to use someone for the good of others if on balance you are their benefactor, and if they were in no position to make the choice for themselves.

\section{Theodicy Adds To the Evils of the World}

The final strictly evaluative anti-theodical criticism of theodicy is a recognition of all of the above, together with a further claim that the practice of generating and endorsing theodicies, rather than justifying or ameliorating evils, actually adds to the evils of the world. This is for two reasons: Firstly, all of the moral criticisms above having been made, to engage in theodicy is to engage in a morally bad practice, and therefore engaging in theodicy increases the amount of morally bad practices that go on in the world, thus adding to the evils of the world. This is the main contention of D. Z. Phillips: '...a theodicy, in the very language it employs, actually adds to the evils it seeks to justify.'

Secondly, according to Terrence Tilley, 'accepting the recommendation of detachment when considering evils may render one oblivious to the commitment, practical wisdom and constancy needed to counteract some evils.' Or, to put it another way, to engage in theodicy is to somehow weaken one's moral responsiveness. James Wetzel agrees.

\section{A Moral Objection to Theodicy Becomes a Moral Objection to Theism}

We have seen that moral anti-theodicy presents a barrage of evaluative criticisms against theodicy. Many of these criticisms are undoubtedly correct: Therefore, theodicy is morally objectionable; by which I mean that it can be objected to on moral grounds, and we have good reason to so object. Theodicy mediates a praxis that sanctions the evils of the world. What I wish to add to this is the observation that, according to my analysis as presented in chapter one, the meta-problem of evil remains a logically binding problem and as such cannot be avoided by any theist (or anyone else for that matter). If a theist wishes to remain a theist in the traditional manner that assumes the maximal-goodness and maximal-power of God, some form of 'meta-theodicy' (loosely understood) is therefore necessary and unavoidable. As such, if theodicy mediates a praxis that sanctions the evils of the world, and theism requires theodicy necessarily, then theism mediates a praxis that sanctions the evils of the world. Or, to put it another way, if theodicy is morally objectionable, and theism requires theodicy, then theism is morally objectionable. To be a theist is to sanction the evils of the world in a morally objectionable way.

\section{The Argument}

- Theism requires theodicy.

- Theodicy is morally objectionable.

- Therefore, theism is morally objectionable.

\section{Theism Requires Theodicy}

The defence of premise 1 was largely made in chapter one, when I discussed the logically binding nature of the problem of evil. There I argued that the problem of evil remains a logically binding problem, even in its 'evidential' form, and as such cannot be avoided by anyone, on pain of contradiction. Everyone must deny at least one premise in this inconsistent set:

- There exists a maximally-good, maximally-powerful creator of the universe.

- A maximally-good, maximally-powerful creator of the universe would not create or permit any pointless or unconscionable evil in its creation.

- $\quad$ Some pointless or unconscionable evil exists.

\section{Implicit Theodicy, Tacit Sanctions}

It ought to be borne in mind that we remain talking at the meta level here, and therefore it is left entirely unspecified what form this 'theodicy' takes. This leaves open the possibility of no theodicy being explicitly stated, leaving the theodicy as an implicit theodicy. This accurately allows for the approach of the sceptical theist, who says nothing whatsoever about what God's reasons for permitting evil are, yet maintains that there are such reasons, and that we ought not to be surprised that we are ignorant of them.

Just as the moral anti-theodicists accuse theodicies of offering a tacit sanction for the evils of the world, so too can we accuse any theist (who has been presented with the problem of evil and remained a theist) of offering an implicit theodicy. The string of entailments, that of theism requiring (at least) an implicit theodicy, and an implicit theodicy offering a tacit sanction of the evils of the world, entails that theism offers a tacit sanction of the evils of the world. That is the contention of this thesis. To be a theist is to offer a tacit sanction of the evils of the world. It is to look at the world, consider its horrors, and deem it 'ok', all things considered. Given the logically binding nature of the problem of evil, this response is essential to theism. 


\section{Theodicy Is Morally Objectionable}

The defence of this premise has largely been made already, since it relies entirely upon the criticisms proposed by the moral anti-theodicists. If their criticisms are correct, then theodicy, even implicit theodicy, is morally objectionable. To deny the evaluative claims made within the second or third propositions of the problem of evil is to make evaluative claims that are morally unthinkable. These unthinkable evaluative claims ought not to be made, and to make them is morally objectionable.

My argument states that, to the extent that theodicy is morally objectionable, theism necessarily inherits that moral objectionability. To be clear, and to reiterate something that I mentioned earlier (albeit in a footnote; see note 2 of this chapter), all I mean by that is that one can, and has good reason to, object to theism on moral grounds. The phrase 'morally objectionable' has connotations though, connotations of 'morally distasteful', 'wrong', 'bad', or 'evil'. I do not intend to make those connotations; 'morally objectionable' is here meant to only mean 'capable of being objected to morally, and there is good reason to so object'. So, to reduce the rhetorical connotations a little, rather than saying 'theism is morally objectionable', we ought probably to say 'theism commits one to making certain evaluative claims, claims that we have good moral reason to disagree with'. But that is a clumsy phrase. And besides, we might have reason not to shrink away from making the bolder claim that theism is 'morally objectionable', in the sense that it is 'wrong', 'bad', or 'evil'.

\section{Morally Objectionable, in a Strong Sense and in a Weak Sense}

In general, when someone makes evaluative claims about something of sufficient moral importance, claims that contrast with your own, we find their claims morally objectionable in the stronger sense; we find those claims to be wrong, morally, and the person who makes those claims is judged to be a bad person in light of them. Consider something like slavery: If someone makes the claim that 'slavery is good', or even 'slavery is not bad', we are naturally inclined to see them as a bad person. There is nothing wrong with this picture; but this is not to say that all cases of contrasting evaluative claims warrant a judgement that the other person is a bad person. Consider something like vegetarianism: A vegetarian might be a vegetarian for moral reasons, thus meaning that they hold evaluative claims (e.g. 'eating meat is wrong') that contrast with meat eaters ('eating meat is not wrong'). But there are many liberal vegetarians who do not see all meat eaters around them as being bad people for that difference in evaluative opinion. Some more extreme or committed vegetarians might, but not all. Whereas, I would say, all reasonable people would judge any supporter of slavery to be a bad person.

\section{Theism is morally Objectionable}

A combination of theism's necessary requiring of theodicy, and the necessary status of theodicy as being morally objectionable, entails that theism is necessarily morally objectionable, at least in the weak sense. This conclusion is entirely dependent upon the success of the anti-theodical criticisms, but chapters five and six argued that at least some of those criticisms were successful. It also depends entirely upon what has been established in chapter one, which claimed that the problem of evil remained a logically binding problem. Clearly, I stack controversial thesis upon controversial thesis here, and if one collapses, then so too does the whole house of cards! But there was another claim in an earlier chapter (chapter three), a claim to the effect that the problem of evil could not be used as an argument against the existence of God, since one cannot reliably derive non-evaluative conclusions from evaluative premises. Given the obviously evaluative nature of the conclusion of this latest argument - Theism is morally objectionable' - it is clear that this cannot be seen as an argument for the non-existence of God. It is, therefore, no reason to resolve the problem of evil in favour of atheism, traditionally understood.

\section{Non-Cognitive Atheism}

It isn't God I don't accept, you see; it's the world created by Him, the world of God I don't accept and cannot agree to accept. [...] It isn't God I don't accept, Alyosha, it's just his ticket that I most respectfully return to him.

Ivan Karamazov, in Dostoevsky's The Brothers Karamazov

I often read that I am atheistic; I hear people speak of my atheism. Yet these words say nothing to me; for me they have no meaning. I do not believe in God and I am not an atheist.

\section{Albert Camus}

I think we should rightly think of Ivan Karamazov and Albert Camus as being atheists. I will argue for the plausibility of a primarily noncognitive atheism. That is, a form of atheism that does not explicitly deny the existence of God, yet nevertheless counts as a full and legitimate form of atheism. To do this, I appeal to a simple argument; two premises that lead to a conclusion: 1 . Atheism is the negation of theism. 2 . Theism necessarily has noncognitive components. 3. Therefore, atheism can be purely noncognitive. Premise 1 is fairly uncontroversial. Premise 2 is the controversial meat of the matter. It is far from clear that all forms of theism must have noncognitive components but, although I would be inclined to make that strong claim, strictly speaking I only need some forms of theism to necessarily have noncognitive components. I will spend some time defending the plausibility of this premise, before proceeding to discuss some consequences of this argument and its conclusion.

If this argument is correct, then it establishes the plausibility of my claim (constructed over the course of previous chapters) that the problem of evil can still be conducive towards atheism, albeit not an atheism that explicitly denies the existence of God. The moral objections to theodicy, and, derivatively, to theism, are conducive towards the establishment of con-attitudes towards God and belief in God. This amounts to a noncognitive rejection of God and belief in God. The argument of this chapter now moves this position on one stage further, claiming that this noncognitive rejection of God 
amounts to a form of atheism. Therefore, the problem of evil remains conducive towards atheism, even if it cannot establish the non-existence of God.

\section{The Argument}

- Atheism is the negation of theism.

- Theism necessarily has noncognitive components.

- Therefore, atheism can be purely noncognitive.

\section{Atheism Is the Negation of Theism}

Atheism is the negation of theism. What it means to be an atheist is to negate or deny what it is to be a theist, and to be a theist is to believe in God. As Robin Le Poidevin says:

Atheism [...] is a definite doctrine, and defending it requires one to engage with religious ideas. An atheist is one who denies the existence of a personal, transcendent creator of the universe, rather than one who simply lives life without reference to such a being. A theist is one who asserts the existence of such a creator. Any discussion of atheism, then, is necessarily a discussion of theism.

The first point to note, therefore, is that to be an atheist 'requires one to engage with religious ideas'. And this of course makes sense; given that something is being denied or negated, it stands to reason that one ought to understand something of what is being denied. One needs a firm enough grasp of what it is to be a 'theist', what it means to assert the existence of God, in order to understand what one means when one declares oneself not to be a theist, to be an 'atheist'. Indeed, one could push Le Poidevin's conclusion further here, and say that not only is any discussion of atheism 'necessarily a discussion of theism', but any position on atheism, for or against, is necessarily a position on theism.

I will proceed from this foundation: Atheism is the denial of belief in God; it is the negation of 'theism', logically 'not-theism'. So to be clear on what 'atheism' is, we must be clear on what 'theism' is. And so for whatever we decide 'theism' is, whatever propositional content we decide that word/ position represents - for simplicity we can label that content with an arbitrary placeholder in some brackets: i.e. theism $=(\mathrm{x})$ - atheism will be a negation of that content: so the propositional content and form of atheism would just be $-(\mathrm{x})$.

Premise 1 is fairly uncontroversial. I therefore leave the defence of premise 1 at that - an appeal to authority, to intuition, and to an illustration of the logical form of what it means to be an atheist, what the proposition of 'atheism' means.

\section{Theism Necessarily Has Noncognitive Components}

Premise 2 is the controversial meat of the matter. I claim that noncognitive content is bound up in what it means to be a theist. And necessarily so; I claim that a theist is not a theist unless they have some noncognitive attitudes, motivations, desires, emotions, etc., bound up, somehow, with their conception of God, and with their affirmation of His existence. This is a prima facie controversial claim, for it denies that standard view of 'theism' as simply meaning a merely cognitive 'one who believes that $\mathrm{P}$ ', where $\mathrm{P}=$ 'God exists'.

(Just to be clear, by 'cognitive components' or content, I mean propositional claims, truth-apt statements. By noncognitive components, I mean that which is not cognitive; the affective or conative parts of thought, from which non-truth-apt statements emerge; expressions of attitudes, emotions, evaluations, etc. I do not mean to say anything controversial here, but use standard terminological distinctions. So when I say 'theism necessarily has noncognitive components', I mean nothing more than 'theism cannot be entirely reduced to cognitive, truth-apt propositions'. Some affective or conative components are involved, from the ground up.)

\section{Theism is a Conjunction}

I ought to mention at this point that I am assuming that theism also has some cognitive components as a necessary part, in addition to the noncognitive. I will not argue for this; I take it as uncontroversial, or at least reasonable, to assume some minimal theological realism. That is, when someone says 'I believe in God', at least part of the meaning of that claim is constituted by the positive affirmation of the cognitive proposition 'It is the case that God exists'. Assuming some sort of minimal theological realism, and assuming I am correct that theism (or at least certain forms of it) necessarily has some noncognitive components, leaves us in the awkward position of finding ourselves on both sides of the cognitive/ noncognitive divide at the same time. What this means is that 'theism', as a position, is a conjunction of two logically distinct conjuncts. We have the straightforward propositional content - 'It is the case that God exists' - conjoined with the non-propositional, noncognitive content, which is, of course, difficult to represent in clear terms. As an expression of attitude, desire, emotion, etc., it is as much a matter of tone as of content. The natural limits of words on a page nudge a poor writer towards italicization ('I believe in God'), or other clumsy means to try and demonstrate this. As an analytic philosopher, I retreat to a vague formalization: $(\phi P)$. I use this as a stand-in to represent whatever noncognitive content is bound up within theism.

\section{Conclusion}

In conclusion, theodicies work by denying some evaluative component of the problem of evil. This much is obvious, really, since it is impossible to deny that (say) earthquakes occur. The evaluative content within the problem of evil is denied by a further evaluative claim; which, again, is rather obvious if we maintain some minimal version of the isought gap: a fact claim cannot be used to directly deny the truth of an evaluative claim (though it can deny the truth of an 
evaluative claim indirectly, by undermining the factual object that the evaluative claim relates to; but this is not what theodicies do).

The response of the moral anti-theodicist is to recognise the central role that these additional evaluative claims play in theodicy, and point out that all of them, in some way, deny (either explicitly or implicitly) an essential moral claim that we ought otherwise to accept as true. For example, Weil's claim regarding the goodness of suffering (if that is not an unfairly glib caricature of her position) denies the essential, well, badness of suffering;

Marilyn Adams's claim regarding the irrelevance of pleasure in the theodical equation denies the essential role that the extreme negation of pleasure, in the form of horrendous suffering, ought to play in this equation; Plantinga and Hick both rely upon a fundamentally mean sends reasoning that denies the essential moral requirement that humans be treated never as mere means, but always as ends in themselves.

My claim is that moral anti-theodicy works by rejecting the moral claims of theodicy. Robert Mark Simpson offers a slightly different reading of the response of moral anti-theodicy. For him, moral anti-theodicy works by making one moral claim - that there is some moral impropriety in sanctioning the horrendous evils in the world - and then accusing theodicy in light of this claim. I do not disagree with him on this point, but consider my reading to be more applicable, given my analysis of the problem of evil at the meta level.

Simpson's reading is certainly correct, but my reading explains why his reading works. Why is there some moral impropriety in sanctioning the horrendous evils of the world? I answer: Because to sanction the evils of the world requires that we deny the moral claims that afford these evils their moral status.

\section{References}

i. Adams, Marilyn McCord, Horrendous Evils and the Goodness of God (Ithaca: Cornell University Press, 1999)

ii. Adorno, T. W., Negative Dialectics, trans. by E. B. Ashton (London: Routledge \& Kegan Paul, 1973)

iii. Almeida, Michael J., and Graham Oppy, 'Sceptical Theism and Evidential Arguments from Evil', Australasian Journal of Philosophy, 81:4 (2003), 496-516

iv. Badham, Paul, Is there a Christian Case for Assisted Dying? (London: SPCK, 2009)

v. Bakunin, Mikhail, God and the State, available at:

vi. <http:// www.marxists.org/ reference/ archive/ bakunin/ works/ godstate/ > [accessed 16/ 09/ 2014]

vii. Barth, Karl, Dogmatics in Outline, trans. by G. T. Thomson (London: SCM Press, 2001)

viii. Becker, Lawrence C., 'Trust as Noncognitive Security about Motives', Ethics, 107:1 (1996), 43-61

ix. Craig, William Lane, 'The Indispensability of Theological Meta-ethical Foundations for Morality', Foundations, 5 (1997), 9-12

x. Cranfield, C. E. B., The Apostles' Creed: A Faith to Live By (London: Continuum, 2004)

xi. Davies, Brian, An Introduction to the Philosophy of Religion, 2nd edition (Oxford: Oxford University Press, 1993)

xii. Dougherty, Trent, 'Skeptical Theism', Stanford Encyclopedia of Philosophy, 2014, available at: <http:/ / plato.stanford.edu/ entries/ skeptical-theism/ > [accessed 09/ 09/ 2014]

xiii. Evans, C. Stephen, 'Moral Arguments for the Existence of God', in The Stanford Encyclopedia of Philosophy, 2014, available at: বhttp:/ / plato.stanford.edu/ entries/ moralarguments-god/ > [accessed 05/ 09/ 2014]

xiv. Frank, Joseph, Dostoevsky: A Writer in His Time (Princeton: Princeton University Press, 2010)

xv. Gaita, Raimond, A Common Humanity (London: Routledge, 2001)

xvi. Gleeson, Andrew, A Frightening Love: Recasting the Problem of Evil (Basingstoke: Palgrave Macmillan, 2012)

xvii. Greenberg, Irving, 'Cloud of Smoke, Pillar of Fire', in John K. Roth and Michael Berenbaum (eds.), Holocaust: Religious and Philosophical Implications (Minnesota: Paragon House, 1989)

xviii. Harrison, Victoria, Religion and Modern Thought (London: SCM Press, 2007)

xix. Hick, John, Evil and the God of Love (London: Macmillan, 1966)

xx. Hugo, Victor, Les Misérables, trans. by Isabel F. Hapgood, Kindle edition (New York:

xxi. Thomas Y. Crowell \& Co., 1887)

xxii. Hume, Cardinal Basil et al., 'The Common Good' and the Catholic Church's Social

xxiii. Teaching: A Statement by the Catholic Bishops' Conference of England and Wales (1996)

xxiv. Kant, Immanuel, Critique of Pure Reason [1787], Werke in zehn Bänden, Wilhelm Weischedel (ed.), Band 4: Kritik der reinen Vernunft: Zweiter Teil (Darmstadt: Wissenschaftliche Buchgesellschaft, 1968)

xxv. Kraal, Anders, 'Has Plantinga “buried” Mackie’s Logical Argument from Evil?',

xxvi. International Journal for Philosophy of Religion, 75:3 (2014), 189-196

xxvii. Le Poidevin, Robin, Theistic Discourse and Fictional Truth', in Revue Internationale de Philosophie, 57 (2003), 271-84

xxviii. Martin, Michael, Atheism: A Philosophical Justification (Philadelphia: Temple University Press, 1990)

xxix. Nagasawa, Yujin, 'A New Defence of Anselmian Theism', Philosophical Quarterly, 58 (2008), 577-96

xxx. Ovid, Metamorphoses, available at: বhttp:/ / www.thelatinlibrary.com/ ovid.html> [accessed 03/12/ 2014]

xxxi. Plantinga, Alvin, God, Freedom, and Evil (Grand Rapids, Michigan: Eerdmans, 1977)

xxxii. Plantinga, Alvin, and Michael Tooley, Knowledge of God (Malden, MA: Blackwell, 2008)

xxxiii. Quine, W. V. O., Two Dogmas of Empiricism', Philosophical Review, 60 (1951), 20-43

xxxiv. Rhees, Rush, 'Suffering', in On Religion and Philosophy, ed. by D. Z. Phillips, assisted by Mario von der Ruhr (Cambridge: Cambridge University Press, 1997), pp. 301-6

xxxv. Schroeder, Mark, 'How Expressivists Can and Should Solve Their Problem with Negation', Noûs, 42 (2008), 573599 
xxxvi. Surin, Kenneth, Theology and the Problem of Evil (Oxford: Blackwell, 1986)

xxxvii. Sutherland, Stewart R., Atheism and the Rejection of God: Contemporary Philosophy and The Brothers Karamazov (Oxford: Basil Blackwell, 1977)

xxxviii. Swinburne, Richard, The Problem of Evil', in Stuart Brown (ed.), Reason and Religion (Ithaca: Cornell University Press, 1977), pp. 81-102

xxxix. Tomassi, Paul, Logic (Abingdon: Routledge, 2007)

xl. Tooley, Michael, 'The Problem of Evil', Stanford Encyclopedia of Philosophy, 2012, available at: বhttp:/ / plato.stanford.edu/ entries/ evil/ > [accessed 03/ 09/2014]

xli. Trakakis, Nick, The End of Philosophy of Religion (London: Continuum, 2008)

xlii. Voltaire, Candide [1959] (New York: Boni \& Liverlight, 1918)

xliii. Whitehead, Alfred North, Process and Reality: An Essay in Cosmology, corrected edition, ed. by David Ray Griffin and Donald W. Sherburne (New York: The Free Press, 1978)

xliv. Williams, Rowan, 'Redeeming Sorrows: Marilyn McCord Adams and the Defeat of Evil', in Wrestling with Angels: Conversations in Modern Theology, ed. by Mike Higton (London: SCMPress, 2007), pp. 255-74 